\title{
Lean Manufacturing Implementation in Malaysian Automotive Industry: An Exploratory Study
}

\author{
Norani Nordin* \\ College of Business, Universiti Utara Malaysia, \\ Kedah, Malaysia. \\ rani@uum.edu.my \\ Baba Md Deros, Dzuraidah Abdul Wahab \\ Department of Mechanical and Material Engineering, \\ Faculty of Engineering and Built Environment, Universiti Kebangsaan Malaysia, Selangor, Malaysia. \\ hjbaba@eng.ukm.my, dzuraida@eng.ukm.my.
}

\begin{abstract}
This paper presents an exploratory study of lean manufacturing implementation in Malaysian automotive industries. A questionnaire survey is used to explore the extent of lean manufacturing implementation. This paper also examines the drivers and barriers that influence the implementation of lean manufacturing. The survey was performed on sixty Malaysian automotive components manufacturing firms. The respondents were chosen from those who are directly involved with lean manufacturing practices such as production and quality personnel. The findings show that most of the respondent firms are classified as in-transition towards lean manufacturing practice. These in-transition firms have moderate mean values for each of the five lean manufacturing practice categories. It is also found that these firms spend more attentions and resources in internal areas such as firms' operation and management, compared to external relationships with suppliers and customers. These firms believe that the factors that urged the implementation of lean manufacturing are the desire to focus on customers and to achieve the organisation's continuous improvement. The results from this survey also revealed the main barriers that prevent or delay the lean implementation. The main barriers to implement lean manufacturing system are the lack of understanding lean concepts and shop floor employees' attitude.
\end{abstract}

Keywords: lean manufacturing, automotive industry, Malaysia, implementation

\section{Introduction}

Heightening challenges in today's global competition have prompted many manufacturing firms to adopt new manufacturing management strategies in order to improve the firms' efficiency and competitiveness. Manufacturing firms has taken lean manufacturing (LM) system as a great management tool and many of them have adopted lean techniques in many different forms and names.
Now, LM has become a widely acceptable and adoptable best manufacturing practice across countries and industries (Holweg, 2007). The ultimate goal of a lean organisation is to create a smooth and high quality organisation that is able to produce finished products concerning the customers demand in the quality looked-for with no waste. However, in reality, many companies are not able to transform themselves to a lean manufacturing

*Corresponding Author 
organisation towards creating the world-class companies. Actually the transformation towards LM is filled with formidable challenges, most particularly to understand the real essence of LM concept and philosophy (Balle, 2005), and also to deal with the cultural differences issues either national or organisational (Fairris and Tohyama, 2002; Herron and Braiden, 2007; Liker and Hoseus, 2008; M. Wong, 2007).

There are a few studies that have been done in Malaysia based on lean manufacturing implementation. Study done by Wong et al. (2009) focussed to examine the adoption of lean manufacturing in the Malaysian electrical and electronics industries. From his study it is found that most of the Malaysian manufacturing industries have been implemented lean manufacturing system to some extent. However, findings based on Malaysian manufacturing industries do not indicate the holistic perspective of lean manufacturing implementation. It is also found that the degree of lean implementation in those industries was based on the average mean score of individual keys of lean practices areas, not the total average mean score.

Therefore, the purpose of this study is to further discuss the LM implementation in Malaysian manufacturing industries. The investigation focuses on the degree of LM implementation in Malaysian automotive industries. In addition, the factors that are capable to hinder or delay the lean implementation process are also investigated. Hopefully this study will help the firm's management to identify the problems to implement an effective LM system.

\section{Literature Review}

The concept of LM was pioneered by a Japanese automotive company, Toyota, during 1950's which was famously known as Toyota Production System (TPS). The primary goal of TPS were to reduce the cost and to improve productivity by eliminating wastes or nonvalue added activities (Womack et al., 1990). During 1980 's there was an intense interest on LM implementation among the western manufacturers because of growing Japanese imports. It became a serious concern to the western producers (Holweg, 2007). After the oil crises in the early of 1990's, in a published book named The Machine that Changed the
World (Womack et al., 1990) by International Motor Vehicle Programme (IMVP), such intense interest of LM concept was again aroused. Then, the concept of LM was transferred across the countries and industries due to its global superiority in cost, quality, flexibility and quick respond (Schonberger, 2007).

LM is a manufacturing strategy that aimed to achieve smooth production flow by eliminating waste and by increasing the activities value. Some analysts even pointed out that if an organisation ignores the LM strategy, the company would not be able to stand a chance against the current global competition for higher quality, faster delivery and lower costs (Flott, 2002; Srinivasaraghavan and Allada, 2006). In a large cross-country analysis done by Oliver et al. (1996) proves that LM principles could produce high performance firms.

LM consists of a large number of tools and techniques. Shah (2003) identified twenty two LM practices that are frequently mentioned in literatures and categorised them into four bundles associated with Just-in-Time, Total Quality Management, Total Preventive Management and Human Resource. Some other researchers also categorised the lean tools and techniques according to the area of implementation such as internally and externally oriented lean practices (Olsen, 2004; Panizzolo, 1998; Shah and Ward, 2003). For example Panizzolo (1998) divided the lean practices into six areas which are process and equipment; manufacturing, planning and control; human resources; product design; supplier relationships; and customer relationships. The first four areas are grouped as internal oriented lean practices, whereas supplier relationships and customer relationships are under external oriented lean practices. This study also confirms that, many firms seem to have difficulty in adopting lean tools that concern with external relationships with suppliers and customers even for high performance firms. Empirical results from this study also prove that lean tools in internal areas are adopted most widely in the firms, where the operation and management methods are more direct.

The change from traditional manufacturing system to lean manufacturing is not an easy task. Achanga et al. (2006) suggested that the success of LM implementation depends on four critical factors: leadership and management; finance; skills and expertise; and supportive organisational culture of 
the organisation. Some researchers also suggested that applying the full set of lean principles and tools also contribute to the successful LM transformation (Herron and Braiden, 2007; James, 2006).

Despite the huge benefits gained from LM implementation is highlighted, in reality not many companies are successful to implement this system (Balle, 2005; Papadopoulou and Ozbayrak, 2005). There are numerous reported problems and issues regarding the failure of LM implementation. Many researchers believed that the main problem lies on the misunderstanding of the real concept and purpose of LM (Balle, 2005; Schonberger, 2007). Some researcher identified the reason of this misunderstanding is due to cultural differences that occurs during transition or translation of LM (Herron and Braiden, 2007; James, 2006). This type of misunderstanding could lead to more major issues such as piecemeal adoption of lean tools and techniques (James, 2006), misapplication of lean tools (Herron and Braiden, 2007; Pavnaskar et al., 2003), and lack of development of lean culture that support the lean development (Jorgensen et al., 2007; Liker and Hoseus, 2008). Study done by Puvanasvaran et al. (2009) showed that the company which is in the early stage to become lean, must keep its efforts for an effective communication process at all levels in order to be successful in LM implementation. Good communication process supports the lean practices in manufacturing.

\section{Research Methodology}

A questionnaire was developed to collect data for this study. In order to achieve the objectives of the study, the Malaysian automotive manufacturing firms were selected as the population. The database was obtained from the 2008 Federation of Malaysian Manufacturers (FMM) and SMIDEC directories. This list of the manufacturing firms consists of electrical, electronic, metal, plastic, rubber and other automotive components. The manufacturing firms involved in this study were ranged from medium to big companies, with more than 50 employees. The decision made in this study is based on the studies done by Shah and Ward (2003; 2007), Bonavia and Marin (2006), and Sanchez and Perez (2000). From their studies it is shown that small manufacturing firms are less likely to implement LM concepts due to certain limitations and barriers. The personnel involved in the survey were those from managing directors, manufacturing and/or production managers and executives, and also quality managers and executives.

The questionnaire was consist of three parts; (a) the background information of the organisation (year of establishment, ownership, number of employees, and quality system certification), (b) the lean manufacturing implementation (lean practices implementation, lean drivers, benefits and barriers), and (c) the respondent information (job title, department and years of employment).

The items of lean manufacturing implementation section were adapted from Shah and Ward (2003) and Panizzolo (1998). The questions were set up on a fivepoint Likert scale to measure the extent of implementation described by each of the items. The scale was ranged from 1 to 5 where $1=$ no implementation, $2=$ little implementation, $3=$ some implementation, $4=$ extensive implementation, and 5 $=$ complete implementation. The prime consideration of the design in this survey instrument was to keep it short and focused in order to obtain an adequate response rate.

The process of developing the questionnaire also included a pilot survey. This pilot survey was used to modify and eliminate the number of variables. Experts from industries and academics were also consulted. The comments and feedback were analysed and a few minor modification were made especially in questionnaire format. Majority of the feedback from the experts gave positive remarks and certify that the questionnaire was acceptable for data collection. Although no new items were added for the data collection phase, but many items were reworded or modified. The questionnaire was then ready for data collection.

In the case of reliability test, Cronbach's alpha was employed to measure the internal consistency of the research instrument. According to Sekaran (2005), reliability measurement is an indication of the stability and consistency of the instrument. The generally agreed value of the lower limit for Cronbach's alpha is 0.70 , although it may be as low as 0.60 in exploratory research (Field, 2006).

The internal consistency of the elements of lean practices and lean barriers were tested by using SPSS reliability analysis procedure. The analysis was 
performed separately for the items of each factor. The summaries of the reliability analysis are given in Table 1. All the results proved high internal consistency with coefficient alpha $\geq 0.70$ and therefore reliable.

Table 1. Reliability test results-lean practices and lean barriers

\begin{tabular}{|l|c|c|c|c|}
\hline \multicolumn{1}{|c|}{ Description } & $\begin{array}{c}\text { No. of } \\
\text { items }\end{array}$ & $\begin{array}{c}\text { Alpha } \\
\text { value }\end{array}$ & $\begin{array}{c}\text { Items for } \\
\text { deletion }\end{array}$ & $\begin{array}{c}\text { Alpha if } \\
\text { item } \\
\text { deleted }\end{array}$ \\
\hline $\begin{array}{l}\text { Lean practices } \\
\text { 1. Process and equipment }\end{array}$ & 9 & 0.871 & - & 0.890 \\
2. Manufacturing planning & 5 & 0.865 & - & 0.865 \\
$\quad \begin{array}{l}\text { and control } \\
\text { 3. Human resources }\end{array}$ & 5 & 0.878 & - & 0.878 \\
4. Supplier relationship & 5 & 0.791 & - & 0.791 \\
5. Customer relationship & 3 & 0.809 & - & 0.809 \\
\hline Lean barriers & 10 & 0.900 & - & 0.900 \\
\hline
\end{tabular}

\section{Results and Discussions}

The initial email was sent to 250 target respondents. The email addresses were obtained from the phone calls made to each of the companies listed in the database. From the emails, 17 emails were failed to deliver. This may be due to the reason that either the email addresses were wrong or the person had been left that company. Another followup email was sent after one week later to remind the respondents who had not responded yet and thanks were given to those who had already returned their questionnaire. A total of 19 responses were returned, 11 of them were online survey and the remaining 7 were sent through email. This actually gave quite a low response rate of $7.6 \%$. However, since the initial response rate was not satisfactory and for this reason another method was seek. To increase the response rate the questionnaire was send to the respondents through postage mail. As a result of this, the number of responses was rose to 61 and consequently the response rate was reached to $24.4 \%$.

\subsection{Respondent Profile}

The first aspects to be investigated were the general background of the respondents and the companies involved. Table 2 shows the general background of the respondents such as the job position and years of employment in the company. It was found that the
Table 2. General background of the respondents in their company $(\mathrm{N}=61)$

\begin{tabular}{|l|r|r|}
\hline \multicolumn{1}{|c|}{ Position in the company } & $\mathbf{n}$ & \% \\
\hline Position in the company & & \\
Production Manager \& Executives & 26 & 42.6 \\
QC/QA Manager \& Executives & 26 & 42.6 \\
Others & 9 & 14.8 \\
Years of employment & & \\
$<5$ years & 20 & 32.8 \\
5-9 years & 18 & 29.5 \\
$>10$ years & 22 & 36.1 \\
\hline
\end{tabular}

respondents were mainly Production and QC/QA personnel. Most of them (36.1\%) have been working more than 10 years in that particular company. They were selected because they have first hand knowledge and experience and they were directly involved to the implementation of lean manufacturing program in their companies.

Table 3 shows the general background of the companies involved in the study. The factors investigated were the types of product, age,

Table 3. General background of the companies involved in the study $(\mathrm{N}=61)$

\begin{tabular}{|l|r|r|}
\hline & $\mathbf{n}$ & \% \\
\hline Types of product produced & & \\
Assembly & 10 & 16.4 \\
Plastic parts & 11 & 18.3 \\
Metal parts & 27 & 44.3 \\
Electronic parts & 10 & 16.4 \\
Electrical parts & 9 & 14.8 \\
Rubber parts & 2 & 3.3 \\
Company age (year) & & \\
New (<10) & 8 & 13.1 \\
Intermediate (11-20) & 26 & 42.6 \\
Old (>20) & 26 & 42.6 \\
Company ownership & & \\
100\% local & 30 & 49.2 \\
100\% foreign & 9 & 14.8 \\
Joint venture & 22 & 36.1 \\
Company size (no. of employee) & & \\
Medium (50-150) & 14 & 22.9 \\
Large (> 151) & 47 & 77.1 \\
Quality management system employed & & \\
ISO9001 & 35 & 57.4 \\
QS9000 & 6 & 10.0 \\
ISO/TS16949 & 43 & 70.5 \\
ISO14000 & 38 & 62.3 \\
OHSAS18001 & 12 & 19.7 \\
\hline
\end{tabular}


ownership, size and quality management system of $(44.3 \%)$. Majority of the companies involved in this study are categorised as intermediate and old companies with $42.6 \%$ each. The old company defined in this study are those which were established more than 20 years ago. By comparison, the intermediate companies are those which have been established between 11 to 20 years. New companies are defined which established less than 10 years ago. The percentage of new companies was only $13.1 \%$.

Other than the company age, respondents were also asked about the size and ownership of the companies. In Table 3, it is shown that respondents were mostly from large companies with more than 150 full-time employees, which exhibits $77.1 \%$. In addition, half of the respondent companies have local ownership (49.2\%), whereas $36.1 \%$ of the total respondent company have joint venture and the remaining $14.9 \%$ have fully foreign ownership.

Regarding the quality system certification, all respondent companies have at least one certification in the relevant field. Examining the results in more detail, it was found out that $70.5 \%$ of total respondent companies are certified by ISO/TS16949. About $62.3 \%$ were certified by ISO14000 and $57.4 \%$ certified by ISO9001. Other types of quality certification such as OHSAS18001 and QS9000 were owned by $19.7 \%$ and $10 \%$ of respondent companies respectively.
Figure 1. Driving forces to implement lean manufacturing

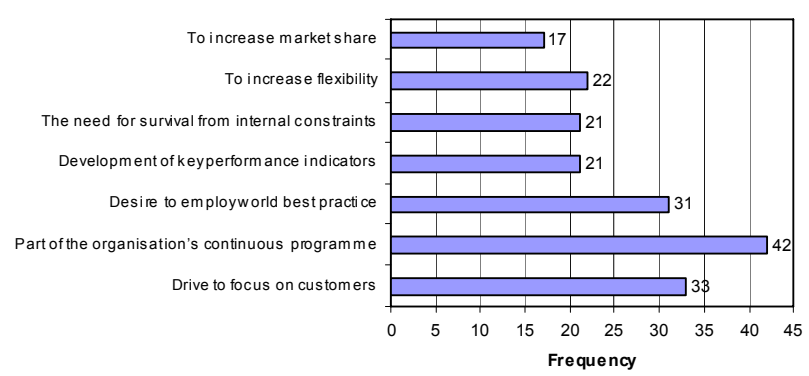

\subsection{Driving Forces to Lean Manufacturing Implementation}

To understand the LM implementation driving forces in Malaysian automotive industries, respondents were asked to indicate the forces that influenced their decision to implement LM. Figure 1 illustrates the driving factors that force the respondent companies to implement LM. As can be seen, the main driver that can influence the implemenation of LM system is the organisation's continuous improvement programme. It exhibits $68.9 \%$ of all driving forces. Beside organisation's continuous improvement programme, other lean drivers that can effect the LM implementation are the customers' satisfaction (54.1\%) and the desire to employ world best practice to the company $(50.8 \%)$. It is surprising to find that the

Figure 2. Distribution of responses based on the adoption of lean manufacturing practices

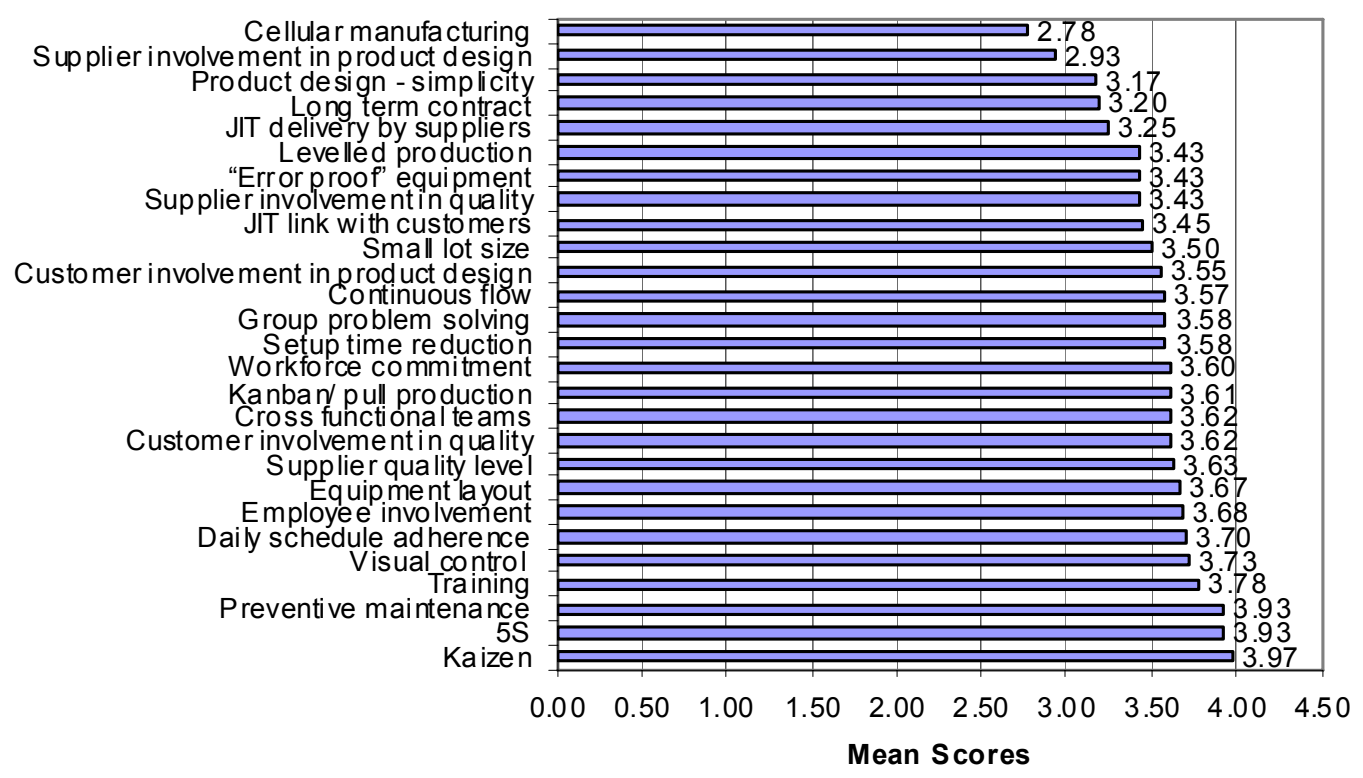


increase market share is the smallest driving factor to implement LM system which exhibits only $27.9 \%$ among all other factors.

\subsection{Lean Manufacturing Implementation}

In order to further verify the extent of lean implementation in Malaysian automotive industries, the respondent companies were asked to rate the level of adoption on each of the lean practices listed based on their current manufacturing practices. Figure 2 illustrates the distribution of LM practice mean scores.

Among all of the LM practices, Kaizen is found to be the leading lean practice, with mean score 3.97. Other lean practices that have been extensively implemented is the $5 S$ (3.93) and preventive maintenance (3.93). However, the least practiced lean tools are the cellular manufacturing and supplier involvement in product design practice. These lean practices have mean score less than 3.0, which indicate having some implementation in the companies. This result agrees with the previous research done by Wong et al. (2009) which highlights that the highest implemented lean practice in
Malaysian electrical and electronics industries is $5 \mathrm{~S}$ and Kaizen. Whilst, group technology or cellular manufacturing is the least adopted lean tools because it demands large investment in equipment and facilities.

LM practices can be categorised into five categories: process and equipment, manufacturing planning and control, human resources, supplier relationships, and customer relationship (Panizzolo, 1998). The list of lean practices that is included in the categories and its mean scores are shown in Table 4.

Table 4 also illustrates the distribution of LM mean scores for each of the category and its practice. The Human resources group shows the highest mean of LM adoption in Malaysian automotive industries. On the other hand the Supplier relationships has the lowest mean score (3.29). These findings confirm the results obtain by Panizzolo (1998) where it was showed that many firms seem to have difficulty in adopting lean tools that concern with external relationships such as with suppliers and customers. These difficulties also occur even for high performers compared to the internal areas of the firm, which are more direct.

Table 4. Lean categories and its mean score.

\begin{tabular}{|c|c|c|c|c|}
\hline Group/category & \multicolumn{2}{|c|}{ Lean practices/ tools } & mean & SD \\
\hline Process \& equipment & $\begin{array}{l}\text { - Kaizen } \\
\text { - } 5 \text { S } \\
\text { - Setup time reduction } \\
\text { - Cellular manufacturing } \\
\text { - Continuous flow }\end{array}$ & $\begin{array}{l}\text { - Equipment layout } \\
\text { - Product design - simplicity } \\
\text { - Error proof equipment } \\
\text { - Preventive maintenance }\end{array}$ & 3.55 & 0.662 \\
\hline $\begin{array}{l}\text { Manufacturing planning } \\
\& \text { control }\end{array}$ & $\begin{array}{l}\text { - Levelled Production } \\
\text { - Kanban/pull production } \\
\text { - Daily schedule adherence }\end{array}$ & $\begin{array}{l}\text { - Small lot size } \\
\text { - Visual control }\end{array}$ & 3.65 & 0.688 \\
\hline Human resources & $\begin{array}{l}\text { - Group problem solving } \\
\text { - Training } \\
\text { - Cross functional teams }\end{array}$ & $\begin{array}{l}\text { - Employee involvement } \\
\text { - Workforce commitment }\end{array}$ & 3.66 & 0.663 \\
\hline Supplier relationships & $\begin{array}{l}\text { - JIT delivery } \\
\text { - Supplier quality level } \\
\text { - Supplier involvement in qu } \\
\text { - Supplier involvement in pr }\end{array}$ & $\begin{array}{l}\text { ment program } \\
\text { and development }\end{array}$ & 3.30 & 0.700 \\
\hline Customer relationships & $\begin{array}{l}\text { - Customer involvement in o } \\
\text { - Customer involvement in p } \\
\text { - JIT link }\end{array}$ & & 3.55 & 0.819 \\
\hline
\end{tabular}




\subsection{Lean Status}

In order to identify the lean status of each respondent company, cluster analysis was performed to classify whether the companies are into lean, in-transition towards lean, or non-lean. Cluster is a group that is computed from the average values of the lean practices variables for all the firms and signifies the extent of the lean manufacturing implementation of that group. Companies were classified as non-lean, in-transition towards lean or lean based on the hierarchical cluster analysis of their mean scores for each individual lean practice using the squared Euclidian distance between variables. Ward's method is used to optimize the minimum variance between clusters. Table 5 shows the mean scores for the three cluster solutions.

As a result of the cluster analysis, the first group (A) has 14 firms and it is characterised having low mean values for all five lean practices variables. This suggests that the firms forming this cluster implement little lean manufacturing practices and for this reason they are categorised as non-lean firms. The second group (B) has 30 firms, and is characterised having moderate mean values for each of the five variables. This group is categorised as intransition towards lean manufacturing system. Finally, the third group (C), which has 17 firms, are classified as lean firms because they have high mean values of each lean manufacturing practices variables. The values suggest that in these firms lean manufacturing practices are extensively implemented in their organisation's operation and management.

The results in Table 5 also show one-way independent ANOVA to determine the significance of the difference between means of cluster. The purpose of this test is to examine the cluster predictive validity and consistency with expected practice levels within groups. To test the homogeneity of variance, Levene test is used for equality of variances. The Levene's test showed that all lean practices are not significant ( $\mathrm{p}>0.05)$ except for Process and equipment. It is assumed in Levene's test that the population variances for each group are relatively equal. Again the F-ratio is used to represent whether the group means are the same. Results for all lean practice show that, $p<0.05$, which significantly states that the mean scores of lean manufacturing practices were different across the lean groups. This proves that the ANOVA results contribute to evaluate the validity of the cluster analysis.

In order to further verify the LM implementation in respondent companies, the implemented tools were also analysed based on the firm status of lean implementation (Table 5). It is found that non-lean firms show more emphasis on human resources during lean tools implementation. On the other hand firms which are in-transition towards lean and lean spend more resources in manufacturing process and control. According to Herron and Braiden (2007), as the companies become stable and become more knowledgeable in their field, they can apply more advance lean tools in order to support the end goal of the production system.

\subsection{Lean Barriers}

To implement lean manufacturing system is not an easy task. For any change in organisation to take hold and success, the resistance forces or barriers need to be identified and understood. Failure to access organisational and individual change readiness may

Table 5. Mean values for three cluster analysis solutions for lean practices

\begin{tabular}{|c|c|c|c|c|c|}
\hline & Non-Iean (A) & In-transition (B) & Lean (C) & \multicolumn{2}{|c|}{ Anova } \\
\hline & $n=14$ & $n=30$ & $n=16$ & $\mathrm{~F}$ & $p$-value \\
\hline Total Lean practices & 2.81 & 3.64 & 4.29 & 164.92 & .00 \\
\hline Process and equipment & 2.81 & 3.50 & 4.27 & 57.36 & .00 \\
\hline Manufacturing process and control & 2.90 & 3.54 & 4.44 & 47.08 & .00 \\
\hline Human resources & 3.10 & 3.50 & 4.39 & 36.80 & .00 \\
\hline Supplier relationship & 2.47 & 3.25 & 4.05 & 57.54 & .00 \\
\hline Customer relationship & 2.74 & 3.47 & 4.35 & 36.51 & .00 \\
\hline
\end{tabular}


Table 6. Lean barriers

\begin{tabular}{|l|c|c|c|c|}
\hline \multirow{2}{*}{ Description } & \multicolumn{3}{c|}{ Mean } \\
\cline { 2 - 5 } & Non lean & In-transition & Lean & Total \\
\hline Company culture & 3.79 & 3.37 & 2.57 & 3.23 \\
National culture & 3.79 & 2.97 & 2.69 & 3.08 \\
Attitude of shop floor employees & 4.00 & 3.50 & 2.88 & 3.45 \\
Attitude of middle management & 3.86 & 3.37 & 2.75 & 3.32 \\
Lack of senior management commitment & 3.93 & 3.10 & 2.94 & 3.25 \\
Nature of manufacturing facility & 3.36 & 2.97 & 2.44 & 2.92 \\
Investment cost & 3.71 & 3.37 & 2.69 & 3.27 \\
Inability to quantify benefits & 3.36 & 3.37 & 2.44 & 3.12 \\
Lack of communication & 3.86 & 3.37 & 2.63 & 3.28 \\
Lack of understanding on LM concepts & 4.14 & 3.70 & 3.25 & 3.68 \\
\hline
\end{tabular}

result the management to spend significant time and energy. Dealing with resistance to change requires a lot of risk and hard work (Barker, 1998; Stanleigh, 2008).

The lean barriers are analysed based on the status of lean implementation by the respondent companies (Table 6), which are indicated from the previous section. The three main barriers in nonlean firms are the lack of lean understanding, lack of senior management and middle management attitudes. On the other hand firms which are intransition towards lean system, most of their barriers are in the lack of lean understanding and employees' attitude. Again for lean firms, lack of lean understanding is identified as the main barrier to implement LM system successfully. Interestingly, all firms recognize the main barrier is the lack of lean understanding. This is because LM requires new knowledge and cultural change during the transition. LM should be applied comprehensively and holistically in principles and concepts (Crute et al., 2003; James, 2006). The ability of people to respond and adapt is critical when they face any change in situation. Appropriate communication and training on the concept and basic principles of LM system would give greater level of understanding about the system and encourage motivation and innovation in the work culture and employees attitudes (Puvanasvaran et al., 2009).

\section{Conclusion}

The purpose of this paper is to explore the extent of LM implementation in Malaysian automotive manufacturing firms. The results show that most of the respondent firms have implemented lean manufacturing system up to a certain extent. Cluster analysis is performed to classify the respondent firms in groups to signify the extent of lean manufacturing implementation or their status from five lean manufacturing practice categories. Majority of the respondent firms are classified as in-transition towards lean because of having moderate mean values for each of the five variables. The firms should aware and understand the lean concept and purpose, because the main barriers of these firms are the lack of real understanding of lean manufacturing concept and employees' attitude. This finding has implication for the firms as it provide a mean to help them to identify the factors that hinder or delay the implementation process. The management should understand and emphasis the importance to overcome these resistance for the successful implementation of lean manufacturing system in their firms. 


\section{Reference}

Achanga, P., Shehab, E., Roy, R., \& Nelder, G. (2006). Critical success factors for lean implementation within SMEs. Journal of Manufacturing Technology Management, 17(4), pp. 460-471.

Balle, M. (2005). Lean attitute - Lean application often fail to deliver the expected benefits but could the missing link for successful implementations be attitude? Manufacturing Engineer, 84(2), pp. 14-19.

Barker, B. (1998). The identification of factors affecting change towards best practice in manufacturing organisations. Management Decision, 36(8), pp. 549-556.

Bonavia, T., \& Marin, J. A. (2006). An empirical study of lean production in the ceramic tile industry in Spain. International Journal of Operation $\mathcal{E}$ Production Management, 26(5), pp. 505-531.

Crute, V., Ward, Y., Brown, S., \& Graves, A. (2003). Implementing lean in aerospace - challenging the assumptions and understanding the challenges. Technovation, 23, pp. 917-928.

Fairris, D., \& Tohyama, H. (2002). Productive efficiency and the lean production system in Japan and the United States. Economic and Industrial Democracy, 23(4), pp. 529-554.

Field, A. (2006). Discovering statistic using SPSS (2nd ed.). London: Sage Publications.

Flott, L. W. (2002). Industry in transition. Metal Finishing, pp. 77-82.

Herron, C., \& Braiden, P. M. (2007, 9-11 July 2007). Defining the foundation of lean manufacturing in the context of its origins (Japan). Paper presented at the IET International Conference on Agile Manufacturing.

Holweg, M. (2007). The genealogy of lean production. Journal of Operations Management, 25(2), pp. 420-437.

James, T. (2006). Wholeness as well leanness. IET Manufacturing Engineer, pp. 14-17.

Jorgensen, F., Matthiesen, R., Nielsen, J., \& Johansen, J. (2007). Lean maturity, lean sustainability. In J. Olhager \& F. Persson (Eds.), IFIP International Federation for Information Precessing (Vol. 246, pp. 371-378). Boston: Springer.

Liker, J. K., \& Hoseus, M. (2008). Toyota Culture: the heart and soul of the Toyota Way. New York: McGraw-Hill.

Oliver, N., Delbridge, R., \& Lowe, J. (1996). Lean production practices: International comparisons in the auto components industry. British Journal of Management, 7(Special Issue), pp. s29-s44.

Olsen, E. O. (2004). Lean manufacturing management: the relationship between practice and firm level financial performance. Unpublished PhD Thesis, Ohio State University, Ohio.
Panizzolo, R. (1998). Applying the lessons learned from 27 lean manufacturers. The relevance of relationships management. International Journal of Production Economics, 55, pp. 223-240.

Papadopoulou, T. C., \& Ozbayrak, M. (2005). Leaness: experiences from the journey to date. Journal of Manufacturing Technology Management, 16(7), pp. 784-807.

Pavnaskar, S. J., Gershenson, J. K., \& Jambekar, A. B. (2003). Classification scheme for lean manufacturing tools. International Journal of Production Research, 41(13), pp. 3075-3090.

Perez, M. P., \& Sanchez, A. M. (2000). Lean production and suplier relations: a survey of practices in he Aragonese automotive industry. Technovation, 20, pp. 665-676.

Puvanasvaran, P., Megat, H., Hong, T. S., \& Muhamad, M. R. (2009). The roles of communication process for an effective lean manufacturing implementation. Journal of Industrial Engineering and Management, 2(1), pp. 128-152.

Schonberger, R. J. (2007). Japanese production management: An evolution - with mixed success. Journal of Operations Management, 25, pp. 403-419.

Sekaran, U. (2005). Research Methods for Business: A skill building approach (Fourth ed.). Singapore: John Wiley \& Sons Inc.

Shah, R., \& Ward, P. T. (2003). Lean manufacturing: context, practice bundles and performance. Journal of Operations Management, 21, pp. 129-149.

Shah, R., \& Ward, P. T. (2007). Defining and developing measures of lean production. Journal of Operations Management, 25, pp. 785-805.

Srinivasaraghavan, J., \& Allada, V. (2006). Application of mahalanobis distance as a lean assessement metric. International Journal of Advanced Manufacturing Technology, 29, pp. 1159-1168.

Stanleigh, M. (2008). Effecting successful change management initiatives. Industrial and Commercial Training, 40(1), pp. 34-37.

Womack, J. P., Jones, D. T., \& Roos, D. (1990). The machine that changed the World: The triumph oflean production. New York: Rawson Macmillan.

Wong, M. (2007). The role of culture in implementing lean production system. In J. Olhager \& F. Persson (Eds.), IFIP International Federation for Information Processing (Vol. 246, pp. 413-422). Boston: Springer.

Wong, Y. C., Wong, K. Y., \& Ali, A. (2009). A study on lean manufacturing implementation in the Malaysian electrical and electronics industry. European Journal of Scientific Research, 38(4), pp. 521-535. 
Norani Nordin is a lecturer with the Technology Management Department, College of Business at Universiti Utara Malaysia. She has BEng and MSc degrees in Manufacturing System Engineering. She is currently doing her PhD in lean manufacturing. Her main research interests are lean manufacturing, industrial engineering, and manufacturing management. Norani Nordin can be contacted at rani@uum.edu.my.

Baba Md Deros is an Associate Professor at the Department of Mechanical and Material Engineering, Faculty of Engineering and Built Environment, Universiti Kebangsaan Malaysia. His research interests span several fields of quality management, benchmarking and ergonomics. Baba Md Deros can be contacted at hjbaba@eng.ukm.my

Dzuraidah Abd. Wahab is an Associate Professor at the Department of Mechanical and Material Engineering, Faculty of Engineering and Built Environment, Universiti Kebangsaan Malaysia. Currently she is the faculty's Coordinator of Graduate Studies. Her research interest are in the area concurrent engineering and sustainable product design. Dzuraidah Abd Wahab can be contacted at dzuraida@eng.ukm.my. 